\title{
EFEKTIVITAS VIDEO TUTORIAL DALAM PEMBELAJARAN KETERAMPILAN MEMBUAT TEMPAT BUAH DARI GELAS PLASTIK BEKAS BAGI ANAK TUNAGRAHITA RINGAN
}

\author{
Wardina Zahra ${ }^{1 *}$, Irdamurni \\ 1,2 Pendidikan Luar Biasa, Universitas Negeri Padang, Indonesia
}

Corresponding Author. E-mail: *1'wardinazahra13@gmail.com, ${ }^{2}$ irdamurni@fip.unp.ac.id

\begin{tabular}{|l|l|l|}
\hline Receive: 13/08/2021 & Accepted: 23/09/2021 & Published: 01/10/2021
\end{tabular}

\begin{abstract}
Abstrak
Penelitian ini bertujuan untuk membuktikan efektifitas video tutorial dalam pembelajaran keterampilan membuat tempat buah dari gelas plastik bekas bagi anak tunagrahita ringan kelas IX di SLBN 1 Ranah Pesisir. Jenis penelitian yang digunakan adalah eksperimen dengan pendekatan Single Subject Research (SSR) desain A-B-A, yang dilaksanakan selama 18 sesi dengan tiga kondisi, yaitu 3 sesi pada kondisi baseline (A1), 9 sesi pada kondisi intervensi (B), dan 6 sesi pada kondisi baseline (A2). Data penelitian ini dikumpulkan dengan teknik observasi langsung dan tes perbuatan menggunakan alat pengumpulan data berupa instrumen tes perbuatan, kemudian dianalisis dengan teknik visual grafik. Hasil analisis data pada kondisi baseline (A1) yaitu 43\%, 43\%, 43\%. Pada kondisi intervensi (B) diperoleh hasil 48\%, 48\%, 57\%, 62\% 52\%, 76\%, 86\%, 86\%, 86\%. Kemudian pada kondisi baseline (A2) diperoleh hasil 67\%, 76\%, 76\%, 86\%, 86\%, 86\%. Hal ini menunjukkan, keterampilan anak tunagrahita ringan dalam membuat tempat buah dari gelas plastik bekas mengalami peningkatan setelah diberikan intervensi berupa video tutorial. Dengan demikian, hasil penelitian menyatakan bahwa video tutorial efektif digunakan dalam pembelajaran keterampilan membuat tempat buah dari gelas plastik bekas bagi anak tunagrahita ringan.
\end{abstract}

Kata Kunci: video tutorial, keterampilan vokasional, tempat buah, tunagrahita ringan

\begin{abstract}
This study aims to prove the effectiveness of video tutorials in learning skills to make fruit holders from used plastic cups for grade IX mild mentally retarded children at SLBN 1 Ranah Pesisir. The type of research used is an experiment with a Single Subject Research (SSR) approach to the A-B-A design, which was carried out for 18 sessions with three conditions, namely 3 sessions on the baseline condition (A1), 9 sessions on the intervention condition (B), and 6 sessions on the intervention baseline condition (A2). The data of this research were collected by direct observation technique and action test using a data collection tool in the form of an action test instrument, then analyzed by visual graph technique. The results of data analysis on the baseline condition (A1) were $43 \%, 43 \%, 43 \%$. In the intervention condition $(B)$ the results obtained were $48 \%, 48 \%, 57 \%, 62 \% 52 \%, 76 \%, 86 \%, 86 \%$, $86 \%$. Then in the baseline condition (A2), the results obtained were $67 \%, 76 \%, 76 \%, 86 \%, 86 \%, 86 \%$. This shows that the skills of mild mentally retarded children in making fruit holders from used plastic cups have increased after being given an intervention in the form of a video tutorial.Thus, the results of the study stated that video tutorials were effectively used in learning the skill of making fruit holders from used plastic cups for children with mild mental retardation.
\end{abstract}

Keywords: video tutorial, vocational skills, fruit holder, mild mental retardation Pendahuluan 


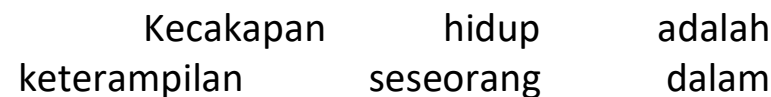
memecahkan berbagai masalah kehidupan yang dihadapi. Bagi anak berkebutuhan khusus, kecakapan hidup sangat dibutuhkan sebagai bekal untuk mencapai kemandirian hidup sehingga mampu menghadapi tantangan kehidupan setelah lulus dari sekolah. Anak berkebutuhan khusus merupakan istilah bagi mereka yang memiliki kelainan atau penyimpangan dari segi fisik, mental, sosial, atau gabungannya, sehingga perlu diberikan layanan pendidikan secara khusus sesuai kebutuhannya (Sumekar, 2009).

Menurut (Irdamurni, tunagrahita merupakan anak dengan gangguan mental intelektual jauh di bawah rata-rata yang menyebabkan hambatan perkembangan pada kemampuan akademik, komunikasi, maupun sosial yang terjadi di bawah usia 18 tahun sehingga memerlukan layanan pendidikan khusus. Tunagrahita kategori ringan memiliki IQ berkisar antara 50-70 atau 75. Meskipun intelegensinya di bawah rata-rata, namun anak tungrahita ringan masih memiliki potensi diri yang bisa dikembangkan.

Upaya yang dapat dilakukan untuk mengembangkan potensi diri anak tunagrahita adalah melalui pembelajaran keterampilan. Keterampilan dalam suatu bidang pekerjaan disebut dengan keterampilan vokasional. Salah satu prinsip dasar dari keterampilan vokasional adalah menghasilkan suatu barang atau jasa (Iswari, 2008). Melalui pembelajaran keterampilan, anak tunagrahita dapat menciptakan berbagai barang yang bermanfaat dan bernilai jual, salah satunya melalui pembelajaran keterampilan membuat kerajinan tangan.

Menurut (Almarogi, 2019) langkah awal yang perlu dilakukan dalam pembelajaran keterampilan vokasional yaitu dengan mengidentifikasi potensi yang ada di sekitar anak yang kemudian diubah menjadi barang yang bermanfaat.

Berdasarkan studi pendahuluan di SLBN 1 Ranah Pesisir, peneliti beberapa kali mengamati pembelajaran keterampilan di kelas IXC dan peneliti menemui ada seorang anak tunagrahita ringan berinisial $A A$ di kelas tersebut yang jarang hadir setiap pembelajaran keterampilan. Kemudian peneliti mewawancarai guru kelasnya. Dari keterangan guru kelasnya, AA memang jarang masuk tidak hanya di hari pembelajaran keterampilan, tapi kadang juga di hari lain karena kata orang tuanya, AA sering sulit bangun pagi dan kadang malas untuk pergi sekolah.

Kemudian peneliti juga menanyakan tentang keterampilan yang sudah pernah diajarkan yaitu keterampilan tataboga, dan membuat kerajinan tangan seperti membuat gantungan kunci, membuat hiasan kotak tisu dari kain flannel, membuat bunga hias dari kain flannel dan sebagainya. Lalu peneliti menanyakan bagaimana kemampuan $A A$ dalam membuat jenis-jenis keterampilan yang pernah diajarkan tersebut dan metode apa yang biasa digunakan guru untuk mengajarkan keterampilan di sekolah, kemudian guru mengatakan AA seringkali kurang antusias dalam membuat keterampilan yang diajarkan tersebut dan guru biasanya menggunakan metode demonstrasi dalam mengajarkan keterampilan.

Pada saat pembelajaran luring, peneliti dan guru kelas mengunjungi rumah AA untuk memberikan pembelajaran dan tugas. Peneliti juga sempat mewawancarai orangtuanya tentang bagaimana keseharian AA ketika di rumah, orangtuanya mengatakan kalau AA suka bermain ponsel dan kadang dia juga bermain bersama teman-temannya. Kemudian peneliti mengamati di lingkungan sekitar rumah $A A$ banyak warung-warung yang berjualan jajanan sekolah sehingga banyak sampah- 
sampah plastik di sekitar tempat tinggalnya salah satunya sampah-sampah gelas minuman kemasan.

Dari segi fisik, AA tidak ada kelainan atau cacat fisik. Hanya saja anak memiliki sedikit hambatan dalam berbicara yaitu kata-kata yang diucapkan terkadang kurang jelas. Menurut guru kelasnya, anak tidak memiliki hambatan pada kemampuan motorik halus dan hasil asesmen keterampilan motorik halus anak menunjukkan bahwa anak mampu melakukan $82,4 \%$ dari aspek yang diujikan, di antaranya anak mampu meremas plastisin, melipat kertas, merobek kertas menjadi beberapa bagian, anak mampu menggunting lurus, menggunting miring, menggunting melingkar, dan sebagainya.

Berdasarkan hal-hal di atas, peneliti tertarik untuk mengajarkan keterampilan baru kepada AA dengan memanfaatkan potensi yang ada di lingkungannya tersebut untuk dikembangkan menjadi kecakapan hidup, mengingat anak yang belum menguasai keterampilan vokasional padahal dia sudah kelas IX. Keterampilan yang akan peneliti ajarkan terkait hal tersebut adalah keterampilan membuat tempat buah dari gelas plastik bekas.

Pentingnya

pembelajaran

keterampilan membuat tempat buah dari gelas plastik bekas ini bagi anak tunagrahita ringan adalah dengan adanya keterampilan ini anak memperoleh keterampilan baru dalam membuat kerajinan tangan dari bahan-bahan yang mudah ditemui. Diharapkan keterampilan ini bisa menjadi bekal kecakapan hidup bagi anak setelah lulus dari sekolah.

Tempat buah yang akan dibuat dalam penelitian ini yaitu tempat buah berbentuk lingkaran dan ukurannya tidak terlalalu besar yang biasanya digunakan sebagai wadah buah-buahan di atas meja makan. Bagian gelas plastik bekas yang akan digunakan sebagai bahan pembuatan tempat buah ini yaitu bagian lingkaran bibir gelas yang kemudian dihiasi dengan pita kawat untuk memperindah dan memperkuat lingkaran-lingkaran tersebut, sehingga menghasilkan tempat buah yang menarik.

Untuk mencapai tujuan pembelajaran keterampilan membuat tempat buah ini, peneliti menggunakan video tutorial sebagai media pembelajarannya. Peneliti memilih video tutorial sebagai media pembelajaran keterampilan ini karena dari keterangan guru kelasnya, AA sangat tertarik kepada media pembelajaran yang menggunakan media digital seperti handphone atau laptop. Selain itu anak juga memiliki smartphone, sehingga dengan adanya video tutorial ini, anak juga bisa terus berlatih membuat tempat buah ini di rumah dengan bimbingan orangtua, apalagi di masa pandemi Covid-19 ini pelaksanaan pembelajaran di sekolah masih belum kondusif sehingga anak lebih banyak waktu untuk belajar di rumah.

Video tutorial merupakan media pembelajaran berbasis audio visual yang menggabungkan unsur gambar bergerak dan suara. Kelebihan dari video tutorial ini yaitu dapat menjelaskan langkah-langkah membuat sesuatu secara lebih rinci, berurutan, dan tentunya akan sangat menarik bagi anak tungrahita karena video tutorial mengandung unsur gambar dan suara sehingga anak tidak cepat bosan dalam belajar. Selain itu, video ini dapat diputar dan dilihat secara berulang-ulang sehingga memudahkan anak untuk memahami suatu pembelajaran (Wati, 2016).

Dalam video tutorial yang peneliti gunakan ditampilkan alat dan bahan pembuatan tempat buah, serta langkahlangkah membuat tempat buah secara bertahap. Penilaian keterampilan membuat tempat buah ini akan dinilai sesuai tahap pelaksanaan membuat tempat buah dari gelas plastik bekas dengan tes perbuatan. 


\section{Metode}

Jenis penelitian yang digunakan adalah eksperimen dengan pendekatan Single Subject Research (SSR). Penelitian Single Subject Research ini berfokus pada kinerja individu (Ledford \& Gast, 2018). Penelitian ekseperimen bertujuan untuk menemukan ada atau tidaknya hubungan sebab akibat dari suatu perlakuan terhadap subjek. Desain Penelitiannya adalah A-B-A. yang mana $A 1$ sebagai kondisi awal subjek sebelum diberi perlakuan, B disebut sebagai intervensi yaitu kondisi subjek selama diberikan perlakuan, dan $\mathrm{A} 2$ disebut sebagai baseline yaitu kemampuan subjek setelah diberikan perlakuan.

Penelitian dilakukan selama 18 kali pertemuan. Setiap pertemuan dilaksanakan pada pukul 14.00 WIB selama 2 jam pelajaran di rumah peneliti. Tempat penelitian disetting dalam sebuah ruangan yang hanya ada peneliti dan subjek penelitian. Adapun subjek penelitiannya adalah seorang anak tunagrahita ringan kelas IX di SLBN 1 Ranah Pesisir, berinisial $A A$, jenis kelamin perempuan, yang berusia 19 tahun. Pada penelitian ini terdapat variabel terikat (yang dipengaruhi) yaitu keterampilan membuat tempat buah dari gelas plastik bekas dan variabel bebas (yang mempengaruhi) yaitu video tutorial.

Data penelitian dikumpulkan dengan teknik observasi langsung dan tes perbuatan dengan menggunakan alat pengumpulan data berupa instrumen tes perbuatan tentang langkah-langkah membuat tempat buah dari gelas plastik bekas. Data dikumpulkan dengan menghitung jumlah skor yang diperoleh anak dalam membuat tempat buah sesuai langkah-langkah pembuatan pada instrumen pengumpulan data. Jenis ukuran target behavior yang digunakan ialah persentase. Kemudian data yang diperoleh dipindahkan ke dalam grafik, lalu dianalisis berdasarkan komponen pada setiap fase baseline dan intervensi dengan dua tahapan yaitu menganalisis data dalam dan antar kondisi. Teknik ini disebut dengan teknik analisis visual grafik.

\section{Hasil dan Pembahasan}

Hasil yang diperolah selama 18 kali pengamatan, yaitu kondisi (A1) diperoleh hasil 43\%, 43\%, 43\%, pada kondisi (B) diperoleh hasil $48 \%, 48 \%, 57 \%, 62 \%, 52 \%$, $76 \%, 86 \%, 86 \%$, 86\%, dan (A2) diperoleh hasil 67\%, 76\%, 76\%, 86\%, 86\%, 86\%. Berdasarkan data yang diperoleh pada masing-masing kondisi, maka dapat digambarkan dalam bentuk grafik berikut:

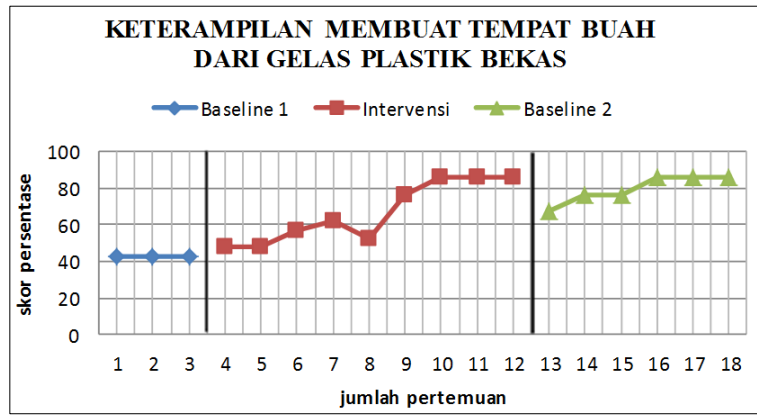

Grafik 1. Rekapitulasi Keterampilan Membuat Tempat Buah dari Gelas Plastik Pada Kondisi A1-B-A2

Berdasarkan grafik 1, tampak bahwa kondisi baseline (A1) dilaksanakan selama 3 sesi dan data menunjukkan stabil pada pertemuan ke-1 sampai 3 dengan persentase hasil yang diperoleh yaitu $43 \%$. Selanjutnya, intervensi (B) berupa video tutorial diberikan pada pertemuan ke-4 selama 9 sesi dan data menunjukkan stabil pada pertemuan ke-10 sampai 12 dengan persentase hasil yang diperoleh yaitu $86 \%$. Kemudian, pada kondisi baseline (A2) dilakukan pengamatan terhadap kemampuan anak setelah tidak lagi diberikan intervensi selama 6 sesi dan diperoleh data stabil pada pertemuan ke-16 sampai 18 dengan persentase hasil yang diperoleh yaitu $86 \%$.

Untuk mengetahui apakah intervensi berpengaruh terhadap target behavior, dapat dilihat berdasarkan hasil analisis data. 
Tabel 1. Rekapitulasi Hasil Analisis Dalam Kondisi

\begin{tabular}{|c|c|c|c|c|}
\hline No. & Kondisi & A1 & B & A2 \\
\hline 1. & Panjang Kondisi & 3 & 9 & 6 \\
\hline 2. & $\begin{array}{l}\text { Estimasi } \\
\text { Kecenderu-ngan } \\
\text { Arah }\end{array}$ & $(=)$ & $(+)$ & $(+)$ \\
\hline 3. & $\begin{array}{l}\text { Kecenderu-ngan } \\
\text { Stabilitas }\end{array}$ & $\begin{array}{c}100 \% \\
\text { (stabil) }\end{array}$ & $\begin{array}{c}11 \% \\
\text { (tidak } \\
\text { stabil) }\end{array}$ & $\begin{array}{c}83 \% \\
\text { (tidak } \\
\text { stabil) }\end{array}$ \\
\hline 4. & $\begin{array}{l}\text { Kecenderu-ngan } \\
\text { Jejak Data }\end{array}$ & $(=)$ & $(+)$ & $(+)$ \\
\hline 5. & $\begin{array}{l}\text { Level Stabilitas } \\
\text { dan Rentang }\end{array}$ & $\begin{array}{c}\text { Stabil } \\
43 \%- \\
43 \%\end{array}$ & $\begin{array}{c}\text { Variabel } \\
48 \% \text { - } \\
86 \%\end{array}$ & $\begin{array}{c}\text { Variabel } \\
67 \%- \\
86 \%\end{array}$ \\
\hline 6. & Level Perubahan & $\begin{array}{c}35-35= \\
0 \\
(=)\end{array}$ & $=\left(\begin{array}{c}86-48= \\
38 \\
(+)\end{array}\right.$ & $\begin{array}{c}86-67= \\
19 \\
(+)\end{array}$ \\
\hline
\end{tabular}

Dari hasil analisis data dalam kondisi, diperoleh panjang kondisi A-B-A yaitu 3-9-6. Untuk kecenderungan arah kondisi A1 tidak mengalami perubahan (=), pada kondisi B mengalami peningkatan $(+)$, dan pada kondisi A2 mengalami peningkatan (+). Dilihat dari kecenderungan stabilitas pada kondisi A1 diperoleh rentang stabilitas $7 \%$, mean level $43 \%$, batas atas $47 \%$, batas bawah $39 \%$, dan persentase stabilitas $100 \%$ (stabil). Pada kondisi B diperoleh rentang stabilitas $13 \%$, mean level $67 \%$, batas atas $74 \%$, batas bawah $60 \%$, dan persentase stabilitas $11 \%$ (tidak stabil). Pada kondisi A2 diperoleh rentang stabilitas 13\%, mean level $80 \%$, batas atas $87 \%$, batas bawah $73 \%$, dan persentase stabilitas $83 \%$ (tidak stabil). Dilihat dari kecenderungan jejak data menunjukkan bahwa pada kondisi A1 tidak mengalami perubahan $(=)$, pada kondisi B mengalami peningkatan $(+)$, dan pada kondisi A2 mengalami peningkatan (+). Selanjutnya pada level stabilitas dan rentang diperoleh hasil A1 stabil dalam rentang (43\% - 43\%), B tidak stabil (variabel) dalam rentang (48\% - 86\%), dan A2 tidak stabil (variabel) dalam rentang $(67 \%-86 \%)$.
Kemudian pada level perubahan terjadi perubahan sebesar $0 \%$ pada kondisi $A 1$, $38 \%$ pada kondisi B dan 19\% pada kondisi A2.

Tabel 2. Rekapitulasi Hasil Analisis Dalam Kondisi

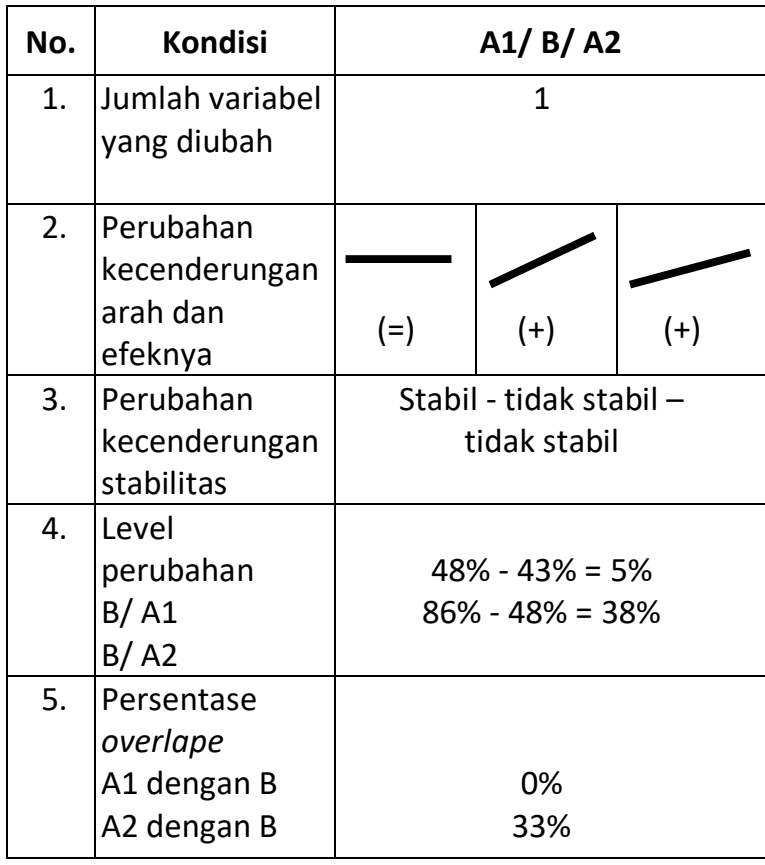

Dari hasil analisis data antar kondisi, jumlah variabel yang diubah adalah 1 yaitu keterampilan membuat tempat buah dari gelas plastik bekas. Perubahan kecenderungan arah menunjukkan pada kondisi A1 tidak terjadi perubahan, pada kondisi B terjadi peningkatan, dan pada kondisi A2 terjadi peningkatan. Berdasarkan hal tersebut, maka pemberian intervensi berupa video tutorial berpengaruh positif pada variabel yang diubah. Selanjutnya, perubahan kecenderungan stabilitasmya yaitu dari stabil ke tidak stabil. Kemudian dilihat dari level perubahan, pada A1 dan B mengalami tingkat perubahan dengan nilai $5 \%$, hal ini berarti bahwa pada kondisi ini terdapat perubahan, selanjutnya antara kondisi intervensi (B) dan baseline (A2) mengalami tingkat perubahan dengan nilai $38 \%$, hal ini berarti bahwa pada kondisi ini terdapat perubahan dengan peningkatan. Dari hasil penghitungan overlape diperoleh 
persentase yang bisa dikatakan kecil, yaitu overlape pada kondisi A1 dan B sebesar $0 \%$ dan pada kondisi B dan A2 sebesar 33\%.

Berdasarkan hasil analisis data di atas, terbukti bahwa video tutorial efektif digunakan dalam pembelajaran keterampilan membuat tempat buah dari gelas plastik bekas bagi anak tunagrahita ringan karena kemampuan anak menunjukkan peningkatan sebagai akibat dari pemberian intervensi berupa video tutorial. Sejalan dengan teori yang kemukakan oleh (Rikarno, 2018) bahwa video tutorial sangat sesuai digunakan untuk proses pembelajaran yang sifatnya praktek. Kelebihan dari video tutorial ini yaitu dapat menjelaskan langkah-langkah membuat sesuatu secara lebih rinci, berurutan, dan tentunya akan sangat menarik bagi anak tungrahita karena video tutorial mengandung unsur gambar dan suara sehingga anak tidak cepat bosan dalam belajar. Selain itu, video ini dapat diputar dan dilihat secara berulang-ulang sehingga memudahkan anak untuk memahami suatu pembelajaran salah satunya pembelajaran keterampilan (Wati, 2016).

\section{Simpulan}

Dari hasil analisis data secara keseluruhan dapat disimpulkan, penggunaan video tutorial dalam pembelajaran keterampilan membuat tempat buah dari gelas plastik bekas bagi anak tunagrahita ringan dinyatakan efektif. Maka dari itu, video tutorial bisa dipertimbangkan menjadi salah satu media dalam pembelajaran keterampilan vokasional bagi anak tunagrahita ringan, salah satunya dalam pembelajaran keterampilan membuat tempat buah dari gelas plastik bekas.

\section{Daftar Pustaka}

[1] Almarogi, A. M. (2019). Implementasi Program Pendidikan Vokasional Sebagai Investasi Bagi Anak Tunagrahita dalam Setting Pendidikan Khusus. Inclusive: Journal of Special Education, 5(01), 49-58.

[2] Gast, J. R. L. \& D. L. (2018). Single Case Research Methodology: Applications in Special Education and Behavioral Sciences. New York: Routledge.

[3] Irdamurni. (2019). Pendidikan Inklusif: Solusi dalam Mendidik Anak Berkebutuhan Khusus. Padang: Prenadamedia Group.

[4] Iswari, M. (2008). Kecakapan Hidup Bagi Anak Berkebutuhan Khusus. Padang: UNP PRESS.

[5] Rikarno, R. (2018). Pemanfaatan Handpone Android Sebagai Media Produksi Video Tutorial Pembelajaran Seni. Melayu Arts and Performance Journal, 11(1), 73-87.

[6] Sumekar, G. (2009). Anak Berkebutuhan Khusus: Cara Membantu Mereka agar Berhasil dalam Pendidikan Inklusif. Padang: UNP PRESS.

\section{Profil Penulis}

Nama saya Wardina Zahra, lahir di Kambang tanggal 13 Januari tahun 2000. Saya seorang Mahasiswi tahun masuk 2017 yang sedang menempuh pendidikan jenjang Strata 1 (S1) di jurusan Pendidikan Luar Biasa, Fakultas IImu Pendidikan, Universitas Negeri Padang. Kegiatan saya saat ini adalah sedang dalam proses menyelesaikan tugas akhir (skripsi) sebagai salah satu persyaratan memperoleh gelar Sarjana Pendidikan. 